\title{
FROM TURKEY TO LITHUANIA: HOW EQUAL WOMEN TO MEN, HOW ACTIVE WOMEN IN PATRIARCHY*
}

\author{
Selen GÖKÇEM \\ Anadolu University, Turkey \\ gkselen@gmail.com \\ https://orcid.org/0000-0002-7948-8330
}

\begin{abstract}
This article aims to examine the recent past of Turkey and Lithuania together with Turkish and Lithuanian woman directors and their movies in the sense of feminist approach. Even though both countries have different historical backgrounds, the period between the 1980s and 1990s have a profound impact on the very similar aspects of both countries such as economic, social, cultural and gender. On the one hand, while Lithuania was gaining its freedom and almost started facing a new era called post-Soviet, on the other hand, Turkish Republic was experiencing its third military takeover throughout its history in the very morning of $12^{\text {th }}$ September 1980 . While Turkey was under military control and restrictions during the 1980s, Lithuania was substantially close to being independent and self-governed. However, these noticeable changes had various side effects during the 1990s mainly on women both in Turkey and Lithuania. Through looking at politic, economic, social and cultural differences, it will be questioned how effective the patriarch is and how women reclaimed their voices to be visible and to fight for gaining their social rights in two different located countries as one in the European Union territory and the other one in Western Asia and Southeastern Europe.
\end{abstract}

Keywords: Lithuanian cinema, Woman Directors, Turkish Woman Directors, Soviet Regime.

\section{KADIN ERKEK EŞİTLİĞí VE ATAERKİL DÜZENDE KADININ ETKİNLİĞI: TÜRKIYE VE LITVANYA ÖRNEĞİ}

\section{Öz}

Bu çalışma Türkiye ve Litvanya'nın yakın geçmişini Türk ve Litvanyalı kadın yönetmenler ve onların filmleri üzerinden feminist yaklaşım ile imcelemeyi amaçlamaktadır. Her iki ülkenin farklı tarihi geçmişleri olsa da 1980'lerden 1990'lara kadar olan dönem, iki ülkenin de ekonomik, sosyal, kültürel ve toplumsal cinsiyet gibi benzer yönleri üzerinde derin etkiler yaratmıştır. Bir taraftan Litvanya özgürlüğünü kazanıp Sovyet sonrası olarak adlandırılan bir döneme girerken, diğer taraftan Türkiye Cumhuriyet 12 Eylül 1980 sabahı tarihinin üçüncü askeri darbesini yaşamaktaydı. 1980’lerde Türkiye, askeri denetim ve kısıtlamalar altında iken, Litvanya bağımsız olmaya ve kendi kendini yönetmeye oldukça yakındı. Bununla birlikte, 1990'lı yıllarda yaşanan bu büyük değişimler özellikle Türkiye ve Litvanya'da yaşayan kadınların üzerinde oldukça farklı etkilere neden olmuştu. Politik, ekonomik, sosyal ve kültürel farklılıklar ışı̆̆ında, bu çalışmada ataerkilliğin ne kadar etkili olduğu, kadınların görünür olabilmek ve toplumsal haklarını kazanabilmek için seslerini nasıl duyurmaya çalıştıkları farklı coğrafyalarda bulunan iki ülke özelinde cevaplanmaya çalışılmaktadır.

Anahtar kelimeler: Litvanya Sineması, Kadın Yönetmenler, Türk Kadın Yönetmenler, Sovyet Rejimi.

\section{INTRODUCTION}

The political and social changes during the period in the 1980s and 1990s in Lithuania and Turkey have had significant impacts on their societies even though both countries have different historical

\footnotetext{
* Presented in Thought Elaboration: Linguistics, Literature, Media Expression TELL ME 2015 Conference in Kaunas Faculty of Humanities, Vilnius University, Lithuania
}

Submit Date: 10.09.2018, Acceptance Date: 17.11.2018, DOI NO: 10.7456/10901100/002

Research Article - This article was checked by Turnitin

Copyright (C) The Turkish Online Journal of Design, Art and Communication 
backgrounds. In the 1980s while Lithuania was still under the occupation of the Soviet communist regime and dreaming about gaining its independence, Turkey was witnessing its third military takeover throughout its history in the very morning of $12^{\text {th }}$ September 1980. All these political and social accumulations have led cultural changes that also had effects on both people's daily lives and significant challenges in every aspect of the social life.

These challenges affected women more than men in different ways. As art is one of the significant ways to represent changes in a society, women making movies in Lithuania and Turkey in that specific period reflected their positions in their communities mostly had patriarchal norms. Thus, it is essential to analyze the period together with its historical background and movies shot by woman directors to compare two different located countries' women living in patriarchal order and their priorities to share with the rest of the world.

\section{Political and Cultural Atmosphere in Turkey and Lithuania}

The 1980s Turkey witnessed tremendous changes that affected the future of the country socially, economically and culturally. The 1980s-military takeover brought severe repression period to the country; however, on the other hand, the 1980s (Gokcem, 2013: 4) "became the site of a great transformation which the concept of repression cannot explain. Another way to put it is to say that repression came to the fore along with another strategy, apparently, its price opposite, one promising freedom in the cultural sphere" (Gürbilek, 2011: 5).

The period lasted three years between 1980-1983 was the military takeover years that the Turkish Republic faced with severe restrictions and changes. According to Boratav, Türel and Yeldan "198183 is the "military phase" characterized by enforced incomes policies, with emphasis on stabilization as a sequel to the shock treatment of 1980, deregulation of internal commodity markets and clumsy and disastrous moves into financial liberalization" (1996: 373). Turkish military was in the mode of saving and bringing the democracy again to the country. As Ihsan D. Dağı argues in his article "Democratic Transition in Turkey 1980-83: The Impact of European Diplomacy" inside the book Turkey: Identity, Democracy, Politics (ed. Kedourie, 2013: 124), "military's self-perception as 'the guardian of the state' and the legacy of military as 'modernizer"', brought the issue of human rights on the agenda, however, people were living under pressure with severe restrictions away from having their rights as humans. According to a Turkish daily newspaper, "the result of the coup is horrible. Around 650,000 people were detained, 230,000 people trialed, 50 were executed, 14,000 lost their citizenship, all political parties, unions, and foundations were closed, 171 were killed under custody, hundreds of thousands of people were tortured, thousands are still missing" (http://www.hurriyet.com.tr/english/home/9884161.asp?scr=1, 2015-02-24)

On the side of Eastern Europe, in the 1980s Lithuania was taking steps towards being independent. Soviet regime lost its power and economically went into a downturn. Meanwhile,

Gorbachev unleashed a reform programme that was to (although not intentionally) bring about the collapse of USSR and the restitution of Lithuania's independence. The reforms carried out under the ethos of Glasnost and Perestroika were designed primarily to restructure the economy in a new era of openness after the repressive regimes of former Soviet leaders" (Ashbourne, 1999: 19). 


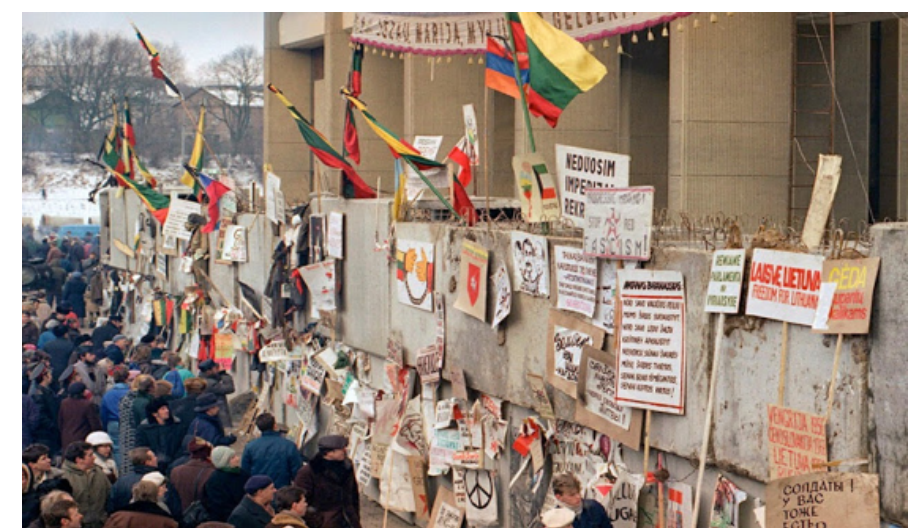

Anti-Soviet political graffiti filled an entire wall in Vilnius on January $17,1991$.

As Ashbourne continues, "the national flag was raised for the first time in public by some of the demonstrators in Vilnius on 14 June in 1988. Sajudis officials had circulated copies of Independent Lithuania's national anthem Lietuva, Tévyne Müsu" (Lithuania, our Motherland) $(1999,22)$. The year 1988 had been momentous for Lithuanians. Lithuanian had become the official language of the Republic. The year 1989 was to prove significant for both the history of Lithuania and the world. On 9 November 1989 the Berlin Wall, the ultimate physical embodiment of the Iron Curtain that had "been drawn across Europe" following the end of World War II, came tumbling down. With it, and remarkably bloodlessly, with the exception of Romania, fell the communist regimes of the eastern and central European Soviet satellite states (Ashbourne, 1999: 23-24).

The collapse of communist regime in 1989 in Eastern and South-Eastern Europe changed the history of those countries together with Europe's. During the transition period, one of the most dramatic changes was in the economy. "During the first half of the 1990s, Lithuania's economy shrunk, unemployment rates increased, and tax revenues declined" (The Lithuanian Department of Statistics 2010). "The transition period from state socialism to an open market economy failed to create and promote equality for Lithuanian women" (Gal and Kligman, 2000). "The situation escalated, and poverty among women increased due to unequal pay, sexist advertising as well as inadequate pensions" (Rakauskiene and Chlivickas, via Stankevicius, 2012).

While Lithuania was in the transition period from state socialism to open market economy and in the way to democratization as an independent country, Turkey was in the period of "modernization" under the military regime and the Prime Minister General İsmet İnönü. In Lithuania, economic situation, a new government and lack of working conditions, in Turkey, restrictions, strict rules and depoliticisation period brought women's position into the question even though it was not consciously intended.

\section{Social Changes and the Effects on Women}

Significant changes in every aspect of society, the economy as being in the first place, also affected the social roles of men and women. In the case of Turkey, the repression period together with its all severe and complicated difficulties brought unexpected positive novelties in the sense of women's movement. Interestingly, "in the repressive and depoliticized atmosphere of the post-coup period, the first social movement that emerged and articulated its demands was the women's movement. It was also the first democratic opposition to the military regime" (Atakav, 2013:2).

Together with the rising of university educated women, consciousness about individuality, working out of the houses -opportunities for educated women, earning and having money out of the men's control, feminism started to be on the agenda of Turkey. However, religion and its culture were still hunting women. Different from Lithuanian patriarchy, the patriarchy in Turkey takes its roots from

\footnotetext{
${ }^{1}$ http://www.vintag.es/2013/09/pictures-of-fall-of-soviet-union-1991.html 2015-02-20
} 
Islam which related with concepts such as honor (namus). As N. Abadan Unat points out (et al. 1981: 219):

\begin{abstract}
Women in Islamic societies including Turkey have been under the influence of religion which elicits the inequality between men and women. In Islamic culture, male honor is closely linked to female purity. Honor requires virginity for the unmarried, fidelity for the married and continence for the divorced or widowed. This concept of honor means that the behavior of an individual woman affects not only her reputation but that all her male kin. The logic consequences have been in general terms; men assume all public roles and women consent to domestic ones.
\end{abstract}

Even though women's movement aimed women's liberation, there was a significant dilemma on women on behalf of becoming unchaste. While on the one hand, women's movement was calling women to have places out of their houses where women were under the control of either their father's or husband's, on the other hand, women were under unbearable pressure of protecting their honors and virginity or avoiding their sexual drives as they were potential "whores" in the eye of men. In this sense, women's movement in Turkey came with the idea of sexual liberation for women because as Kandiyoti points out (Kandiyoti via Gokcem, 2013: 13):

The corporate control of female sexuality, the psychological effects of sex segregation and characteristics of the female life cycle were the most unresolved problems of Turkish women that should be questioned to understand or to carry women from the stage of emancipation to liberation.

The father figure which is used to describe the state in Turkey as "father state" is another aspect to understand how deep the patriarchy and the male control in the society. As Sam Kaplan writes (2006, 14):

In the case of Turkey, the state commands a paramount position in the moral and political imaginaries of all citizens. Whenever one reads about national statesmen in the press, whenever one listens to townspeople and villagers comment on domestic politics, one often comes across the concept of the "father state" (devlet $b a b a$ ). The state as a father figure is a master trope of power to which many Turkish citizens appeal in making sense of their relationship to the state and government representatives.

Different from the situation in Turkey in the case of women's sexual freedom or concept of honor, in the fact of Lithuania, nationalism was on the agenda and thwarted women's movement. Lithuanian women's movement's first aim was not the sexual liberation of women yet equality not only by law but also by the society that also has patriarchal codes. These patriarchal codes even in the socialistcommunist Soviet regime continued to reign even though "a major political goal of the Soviet was complete economic, political and sexual equality for women, Soviet women did not enjoy the same position as men in society and within the family. Working women continued to double burden of a job and family raising responsibilities in which men participated little" (Stankevicius, 2012: 12). Even after the collapse of the Soviet regime, which also made people to get married and have families to raise children as a citizen and new labor force in the name of the country, in independent Lithuania, the double burden of women continued together with the unemployment. There were more "singleparent families headed by women. As a result, the loss of social safety net increased women's dependence on men and state" (2012:4).

As Virginija Juréniené argues in her paper Gender Roles in Lithuanian Society:

The re-created Lithuanian women's movement in 1990-1991 can be called a stage of feminism development because Lithuanian women's awareness was expressed by a structure that allowed to speak about the freedom and self-realization. On the other hand, this stage is closely intertwined with Lithuanian nationalism" which 
can be taken as a "value system that clearly distinguishes and rejects the gender topic."

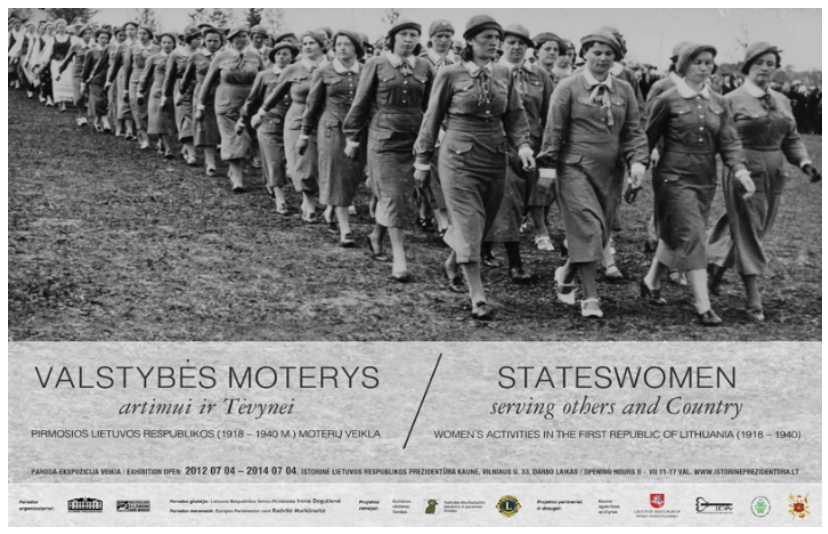

For the first time in the history of European women's movement, two outstanding Lithuanian women Gabrielè Petkevičaitè-Bitè and Felicija Bortkevičienè - were nominated candidates in the presidential election of the state. Neither of them won, but the fact speaks for itself. ${ }^{2}$

From a normative point of viewpoint, Lithuanian laws ensure equal opportunities and rights for women and men and do not discriminate citizens by gender. However, from a factual perspective, there are a lot of gender-related problems in practice. Institutional, political, ideological and cultural factors hindered the realization of equal opportunities. In particular, cultural factors related to society's attitudes are important because they contribute to daily discrimination of gender (Tereškinas, via Juréniené, 2010).

Despite the gender inequality, both in Turkey and Lithuania women's movement has had a negative meaning especially after the definitions "feminism," and "feminist" started to have their places in both languages. One of the reasons of this negativity comes from the men who support patriarchal norms and do not want to eliminate its benefits, and the other reason is women who do not want to be marginalized in the society as supporters of feminism or women who do not understand the importance of feminist ideas. However, in spite of patriarchal codes, there are woman filmmakers who make films in contrary to the notion that making a movie is a man thing.

\section{Working Women: Cinema and Woman Filmmakers in 1980s and 1990s}

Tremendous and unexpected changes not only affected both Turkey and Lithuania's politic and economic situation but the cultural climate. Cinema has helped to initiate women directors to make movies with their perspectives as one of the most effective weapons to reflect the era's overall atmosphere. However, to understand the general tendency in the cinema of the period, it is necessary to make a complete evaluation.

Before Lithuania broke off from the Soviet Union in 1990, filmmaking in Lithuania was financed on the model, applied across all of the former Soviet Union. Until 1990, Lithuania produced seven features films, forty documentaries, and two animation films yearly, with a variation in these numbers. Of the seven features, there were shot for theatrical release across the Union; four were commissions from the Gosteleradio (Central Television Station in Moscow). Of the forty documentaries, eight were shot for theatrical release across the Union, twelve for the local theatrical consumption and around twenty were documentaries commissioned by either Lithuanian or the Union's agencies and institutions. The first independent film production studio Kinema was founded by the director of Šarũnas Bartas in 1987. However, after Lithuania regained independence in March 1990, the state

\footnotetext{
${ }^{2}$ http://www.ciurlionis.lt/ 2015-02-21
} 
funding of filmmaking drastically decreased, and smaller studios emerged instead (www.lfc.lt. 201502-24).

As it is expected, the filmmakers of the era tended to make films dealing with the forbidden subjects during the Soviet regime. And some others particularly young filmmakers wished to make films not dealing with the post-Soviet but with subjects such as existentialism or patriarchy and new values about gender issues. Film critic Živile Pipinyte presented the program of the $6^{\text {th }}$ International Vilnius Documentary Film Festival took place from October 9 to 18 and made ad speech about the feature debut films shot during the period 1980s and 1990s (http://www.lfc.lt/en/Page $=$ ArticleList\&ID $=6697 \& Y=2009 \quad 2015-02-25) *^{3}$

In the 1990s, a new generation of filmmakers came to Lithuanian cinema. Straight away they declared their attitude towards films and reality clearly and forcefully. The years $1985-1989$ were dramatic turning-point years in Lithuanian cinema when the entire Soviet system of financing, production, and distribution of films collapsed. Censorship, until then inseparable from the film industry, collapsed soon, too. The older generation of filmmakers tried to take the opportunity to speak about issues that had been forbidden before post-war resistance and deportations; they wanted to honour public and cultural figures pushed to obscurity. Most often such films could not avoid a declarative tone... Yet young film directors clearly did not want to identify either with the idealised past of inter-war or with the present that was becoming increasingly like a caricature (which came with the freedom of consumption and the spreading mass culture) The resulting films, In Memory of a Day Gone By by Šarūnas Bartas (1990), Ten Minutes before the Flight of Icarus by Arūnas Matelis (1990), Earth of the Blind by Audrius Stonys (1991) or Autumn Snow by Valdas Navasaitis (1992) as well as Illusions by Diana and Kornelijus Matuzevičius (1993), express a desire to speak about existential issues and, first of all, about one's solitude in the alien world, about the meaning of life and feelings, about the temporariness of being and the clash between patriarchal and new values. A film by Algimantas Maceina, Black Box (1994), which documented the transfer of his grandfather's remains from Siberia to is still one of the most original experiments in Lithuanian documentary cinema.

The Idylls of Kirtimai by Arturas Jevdokimovas (1991) is one of the rare attempts in Lithuanian documentary cinema at anthropological observation. The world of these films is empty, abandoned, crumbling; it is, as if, seen through the eyes of lonely people. At the same time, it shows an inner landscape because people interact with reality comparatively freely, although they are aware of the principles of observation (even on the contrary). The static camera of their films likes to record time; time becomes the subject of films. The early works by now famous and recognized filmmakers expressed the human condition in the face of the great historical transitions quite accurately. These directors do not trust words; thus, there are very few of them or even none in their films. They trust images, however. Images in their films become symbols and metaphors; they reflect not only the external reality, but they are, first of all, a reflection of an inner reality. Consequently, their films are often inner monologues, cinematographic meditations on reality and philosophical narrations about the hidden meaning of the world, about the presence of humans and other creatures on Earth.*

While the films giving the general climate of Lithuania were shot by male directors, even though their numbers are not as much as male directors, there are Lithuanian woman directors that created films with or without feminist ambitions. During the 1990s, there were two women directors made movies, Giedrè Beinoriūtè and Janina Lapinskaitè. Giedrè Beinoriūte has two shorts with the names Mano vienišos draugès (My Lonely Friends, 1997) and Mama, tètè, brolis, sees (Mom, Dad, Brother, Sister,

\footnotetext{
${ }^{3} \mathrm{http}: / /$ www.lfc.lt/en/Page=ArticleList\&ID=6697\&Y=2009 the author preferred to use the whole opening speech of Lithuanian cinema as both it gives necessarily historical background and as it is challenging to reach English information about Lithuanian cinema. That's why this whole statement becomes precious one to share in this article.

*Vilnius Documentary Film Festival: The turning-point generation has forcefully declared its attitude towards cinema and reality

"Vilnius Documentary Film Festival: The turning-point generation has forcefully declared its attitude towards cinema and reality
} 
1999) and six others called Trolleybus in 2002, Existence in 2004, Vulkanovka in 2005, Before Flying Back to the Earth in 2005, Grandpa and Grandma in 2007 and Balkanas in 2008. Janina Lapinskaite has six films with the names Tai mano likimas (This is my fate 1994), Iš skruzdèliu gyvenimo (From the life of Ants 1994), Iš elfu gyvenimo ( From the life of elves 1996), Venera su katinu, arba Iš peteliškiu gyvenimo (Venus with Cat or From the Life of Butterflies 1997), Išs avinèliu gyvenimo (From the Life of Lambs 1998) and Kelioniu magija, (The Magic of Journeys 1999).

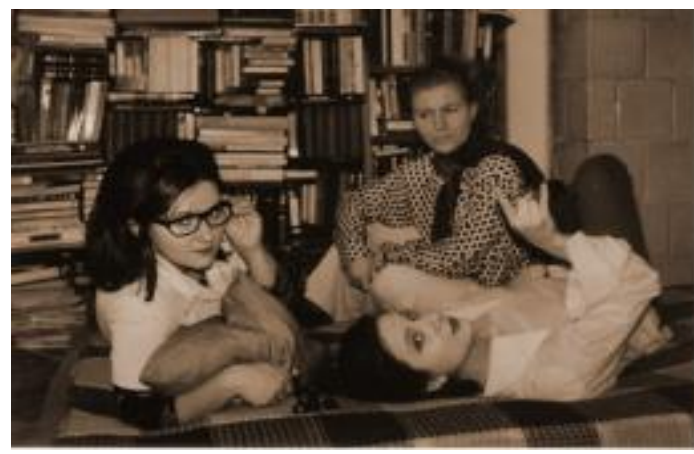

Mano vienišos draugès, 1997

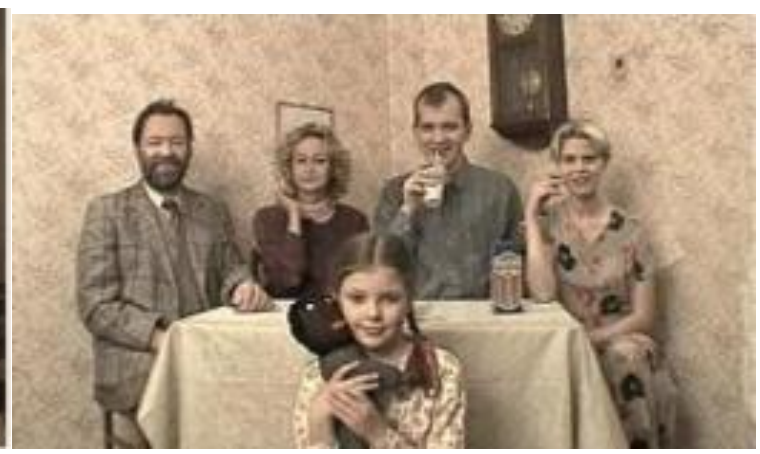

Mama, tèté, brolis, sesé, 1999

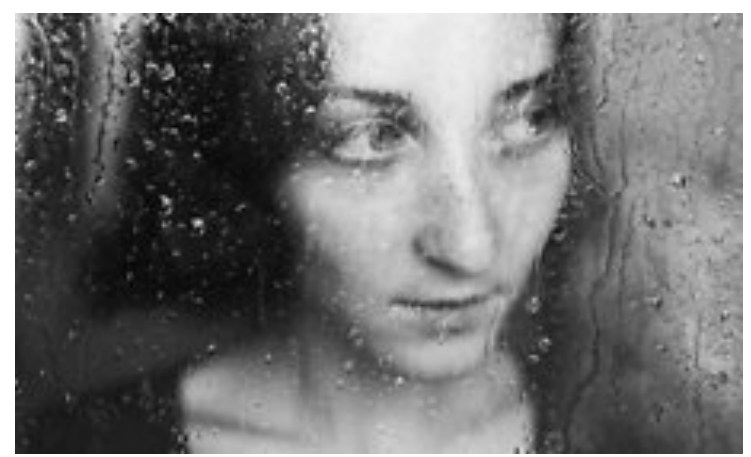

Tai Mano Likimas, 1994

When it is analyzed the examples from these films mentioned above, it is clear that Giedre Beinoriūte deals with a documentary about five single girls' life and focuses on the drama of a family with a problem of human alienation. On the other hand, Janina Lapinskaite prefers to create characters in her films from margins of society, eccentric hermit and she characterizes her films by a combination of poetry and realism.

Turkish cinema in the 1970s, before the military regime, was producing action or sexploitation films for the male audience due to the decline of the family audience in the cinemas. However, while sex scenes and nudity in those sexploitation films were used to attract attraction of the male audience, during "the late 1980s and early1990s sexuality was emancipated women's sexuality that does not serve for male appetite but women's satisfaction" (Gokcem, 2013: 20).

In her book Sinemanın Dişil Yüzü/ Türkiye'de Kadın Yönetmenler (2004), Ruken Öztürk points out that there are "24 Turkish woman directors who made 96 films until 2002. However, as it was not that easy to have a place in males' worlds-because making film was a male thing-, some of these woman directors had to act like men and left their woman sides behind the doors". In spite of the patriarchal pressure, there were still some woman directors made woman themed films in the late 1980s and early 1990s; Nisan Akman with her movie Dünden Sonra Yarından Önce, (1987, After Yesterday Before Tomorrow) Mahinur Ergun with Medcezir Manzaralarl, (1989, Views of Tide), Canan Gerede with Robert'ın Filmi, (1992, Robert's Movie) and Seçkin Yasar with Sarı Tebessüm,(1992,Yellow Smile). All these woman directors put feminism, the emancipation of women, women's sexuality together with the social, political and cultural changes of the era. 


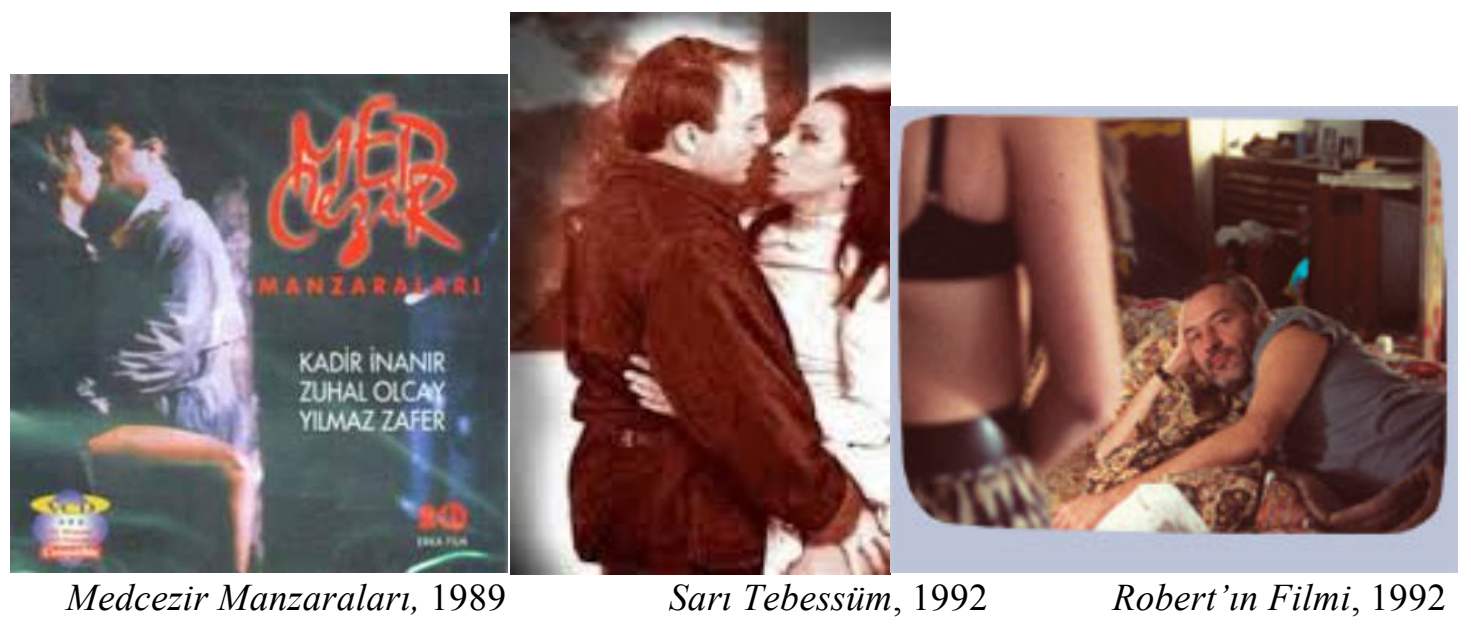

Theme based differences did not affect the attempt of woman directors tried to put their beliefs in their films. While Turkish woman directors were seeking for emancipation from sexual taboos and trying to show that this freedom is one of the most significant ones as feminism were ringing the doorbells for the equality, on the other hand, Lithuanian woman directors were reflecting the vital emotions such as human alienation, loneliness and margins of society as people who achieve victory over Soviet Union. As Virginija Jureniene points out:

After the reestablishment of independence on March 11, 1990, gender equity became one of the most topical issues in the fields of the labor market and politics in Lithuania. From 1945 till 1990, when USSA occupied the state, there was no unemployment problem. Every adult citizen had to work. There was no market, because of the planned economy. Just after 1990, the issue of unemployment became topical, mainly from a women's perspective since women were dismissed in numbers. This solution of the problem was not new from a historical viewpoint, as it had been made during the first Republic of Lithuania (Jureniene, 2008).

As Lithuanian women were used to working under the Soviet regime and earn their own money, it was difficult for them to lose their jobs because of the gender inequality. In Lithuania, "the transition to market economy raised a sex problem in employment. The society was trying to preserve traditional patriarchal relations where a man's, a father's role was more important than the one of a woman. Hence, when the state's economy was in crisis from 1990 to 1996 , women were the first to be dismissed" (Jureniene, 2008). In this sense, it is not difficult to say that patriarchy was stymieing Lithuanian women to have their work rights although the number of women with education was higher than men.

It is not a coincidence that the Turkish movies mentioned here include highly educated women characters who believe to have the same rights with men to declare their sexual needs. However, as the society and even highly educated male characters were trying to preserve traditional patriarchal norms in Turkey during the 1990s, women who transgress the limits of their gender-especially sexual limits in Turkish women case- faced with hostility in their relationships. Even though feminism was oncoming and many women started to raise their voices on the streets, and women directors put priority women issues in their films, patriarchy was ready not to accept these righteous screams for equality.

As a matter of fact, despite the fact that woman directors could manage to make movies with taboo subjects, they were not able to avoid the patriarchal pressure on them. In that sense trying to accept feminism and women's movement as it has occurred in the West and to expect that the whole process and new ideas would fit in countries such as Lithuania and Turkey at once is one of the problems and also one of the reasons that women's movement does not work as it is supposed to. 


\section{CONCLUSION}

The 1980s and 1990s were a crucial period for both Turkey and Lithuania in the sense of politic, economic and cultural changes. The collapse of the Soviet regime in Eastern Europe and the transition period together with the economic shift from socialism to open market economy affected women in Lithuania negatively. Even though women were getting "more active at the end of the 1990s for fighting for their rights in the labor market" (Jureniene, 2008), some of the problems "remained more or less the same as the early years, e.g. negotiation of women's organizations with the government and establishment of women's non-governmental organizations to deal with specific issues" (Jureniene, 2008). While Lithuanian women had their places in working places equally with men, some of the Lithuanian women directors were dealing with margins of society, alienation and loneliness in a more poetic or realist sense as one might say to reveal what they were going through.

On the other hand, in Turkey, Turkish military was trying to save and bring back the democracy to the country; thus, from 1980 to 1983 military takeover was on the agenda. Even though because of the military takeover there was massive pressure on people and had severe restrictions in their lives, surprisingly feminism was blooming for women who had a right to vote but not equal life standards with men inside and outside their houses. Under this climate, some of the Turkish women started to talk about feminism and marched on the streets for their rights.

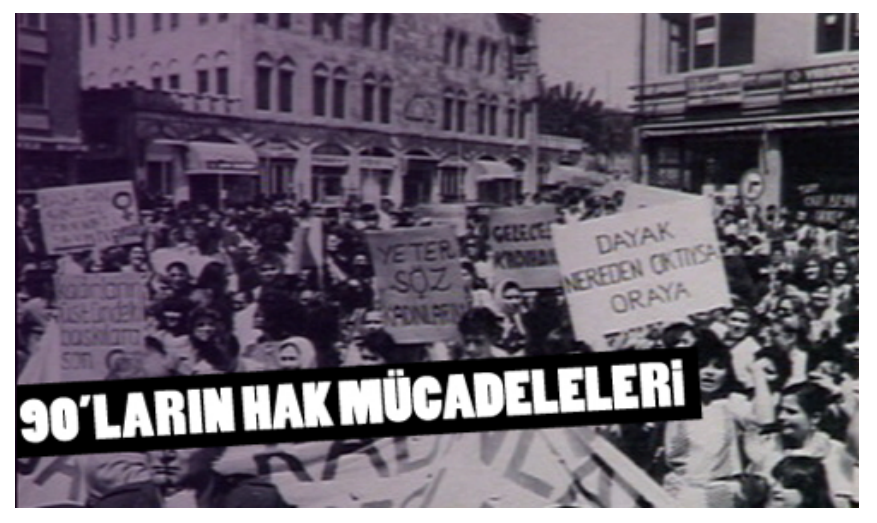

Turkey, 1987. Thousands of women were on the street for violence against women, and for many of them, this marching was the first step to know about feminism. ${ }^{4}$

Some of the Turkish woman directors chose common problems of women living in Turkey and tried to reveal them through their films. Although most of the woman population was not educated enough and their urgent needs were not their sexual freedom, sexuality as a taboo subject for most Turkish people was to be raised by Turkish woman directors through their movies. Different woman directors focused on a various aspect of feminism but four crucial of them- Nisan Akman, Canan Gerede, Mahinur Ergun and Seçkin Yasar- mentioned highly educated women and their relationships with highly trained men which end up in disaster and hostility. It was crucial to bring up educated women and men situation and their relationships to the agenda to show the feminist approach was not working even in educated people while more than half of the population was far from this standard of living.

Showing the inequity of patriarchy in both countries faced similar historical, political, economic changes and difficulties though woman directors' movies are significant to analyze. Both countries indicate that it was not easy for women living far from Western societies to raise their voices and to be accepted as equals and also it was a great attempt to focus on their needs the ones as to be raised up in their movies. Thus, it can be said that form Turkey to Lithuania, although women emancipation and

\footnotetext{
${ }^{4}$ http://bianet.org/bianet/kadin/162876-mor-cati-siginaksiz-bir-dunya-icin-feminist-siginak-mucadelesi 2015-04-18
} 
satisfaction level were not as wanted, women living in the 1980s and 1990s after severe changes were brave enough to chase their dreams.

\section{REFERENCES}

Ashbourne, Alexandra. (1994). Lithuania: The Rebirth of a Nation, 1991-1994. England: Lexington Books.

Atakav, Eylem. (2013). Women and Turkish Cinema: Gender Politics, Cultural Identity and Representation. USA, and Canada: Routledge.

Boratav, Korkut. Türel, Oktar ve Yeldan, Erinç. (1996). Dilemmas of Structural Adjustment and Environmental Policies under Instability Post-1980 Turkey. World Development Vol.24 No:2 p 373393. Elsevier Science Ltd, Great Britain.

Daği, İhsan, 'Democratic Transition in Turkey, 1980-83: The Impact of European Diplomacy in Sylvia Kedourie (ed.), Turkey, Identity, Democracy, Politics. (1996). London.

Gokcem, Selen. (2013). Never Satisfied Dissatisfied Women Hysteric Men in 1980s Turkey. Deutschland. LAP LAMBERT Academic Publishing.

Gal, Susan. \& Kligman., Gail. (2000). The Politics of Gender After Socialism. Princeton University Press.

Gürbilek, Nurdan. (2011). The New Cultural Climate of Turkey: Living in a Shop Window. (Victoria Holbrook Trans.) London: Zed Book.

http://www.lfc.lt/en/Page $=$ ArticleList\&ID $=6697 \& Y=2009$ 2015-02-25

http://www.hurriyet.com.tr/english/home/9884161.asp?scr=1, 2015-02-24)

Jureniene, Virginija. (2008). Women's Position in Lithuanian Labour Market in the 20th century. Amnis [En ligne], 8 | 2008, mis en ligne le 01 septembre 2008, consulté le 25 décembre 2017. URL: http://journals.openedition.org/amnis/529; DOI: 10.4000/amnis.529

Juréniené, Virginija. (2010). Gender Roles in Lithuanian Society. Global Journal of Human Social Science. Volume 10. Issue 6 (Ver 1.0) October, GJHSS- AClassification FOR 170105,170113,220311,220319

Kaplan, Sam. (2006). The Pedagogical State: Education and the Politics of National State in Post1980 Turkey. Standford University Press.

Öztürk, Semire, Ruken. (2004). Sinemanın 'Dişil' Yüzü Türkiye'de Kadın Yönetmenler. İstanbul: Om Yayınevi.

Stankevicius, Simona. (2012). Lithuanian women in the Parliament: Access and participation in postsocialist politics. Unpublished Master's Thesis. Depaul University.

Unat, Abadan, Nermin. (1981). Women in Turkish Society. Printed in Hungary. 